\title{
When soft spaces harden: The EU Strategy for the Baltic Sea Region
}

Jonathan Metzger

Division of Urban and Regional Studies/

Department of Urban Planning and Environment

KTH - Royal Institute of Technology

Stockholm, Sweden

Jonathan.metzger@abe.kth.se

Peter Schmitt

Nordregio

Nordic Centre for Spatial Development

Stockholm, Sweden

peter.schmitt@nordregio.se

\section{PRE-PROOF VERSION, ACCEPTED FOR PUBLICATION IN}

\section{ENVIRONMENT \& PLANNING A}

Acknowledgements: An earlier version of this paper was presented at an Exploratory

Workshop on 'Planning for Soft Spaces across Europe' at the TU Delft (Netherlands), 9 - 10

December 2010, sponsored by the European Science Foundation (ESF). The authors would

like to thank the workshop participants for all the interesting discussions and reflections and

in particular the convener, Bas Waterhout for giving us the the opportunity to develop our

ideas. Finally, we wish to extend our gratitude to the three anonymous referees whose

insightful comments provided considerable help and guidance in improving the quality of

this paper.

Word count, incl everything: 9978 


\section{Abstract:}

This paper investigates the first ever so called 'macro-regional strategy' developed under the aegis of the European Commission: the European Union Strategy for the Baltic Sea Region (EUSBSR). Through a drawing-together of elements of actor-network theory and regionalization theory, it is argued that the adoption of the EUSBSR can be seen as a milestone within a wider process towards Baltic Sea regionalization, whereby the Baltic Sea region is increasingly 'solidified' through the positioning of the European Commission as a spokesperson for the interests of the region. It is further suggested that, if not seriously contested, the possible acceptance of the European Commission as a designated regional spokesperson might be a crucial step in a process whereby the soft space of the Baltic Sea Region gradually may become more formalized. Nonetheless, caution must be taken so as not to confuse degrees of formal institutional fixity with degrees of durability.

KEYWORDS: Baltic sea, EU, EUSBSR, regionalization, spokesperson, soft spaces, metagovernance. 


\section{Introduction}

June 2009 saw the adoption of a major strategic policy document outlining the territorial future of the Baltic Sea Region (BSR): The European Union Strategy for the Baltic Sea Region (EUSBSR) (CEC 2009a and 2009b). This document sets a framework for a number of jointly agreed initiatives designed to strengthen transnational territorial cooperation around the Baltic Sea. The approval of the strategy by the Council of Europe also marked the launch of a new 'macro-regional' policy approach in the EU, as it was subsequently also announced that this strategic policy paper for the BSR may be viewed as a forerunner for the implementation of future additional macro-regional strategies across the European Union. At present, the concept of the macro-region is a moving target, as new strategies for different transnational parts of the EU territory, and partly also beyond, such as the Danube Basin (adopted), the Adriatic and Ionian Sea (proposed) and the North Sea-English Channel (suggested) are in various stages of initiation, formulation and implementation (see also figure 1).

Even if these strategies-in-the-making all have considerably divergent geographical scopes and thematic foci, the increased application of the general concept of the macro-region within an EU policy framework marks a turning point. Previous European strategic territorial policy documents such as the European Spatial Development Perspective (ESDP) (CEC 1999) and the Territorial Agenda (CEC 2007) have been joint efforts by the Member States, but with the advent of the macro-regional approach it now appears to be the EU Commission is taking the driving seat with regards to this new territorial policy approach, backed-up by other EU institutions, the European Parliament and the Committee of Regions. Observed in 
this light, the concept of European macro-regions can be regarded as one of the most radical innovations in European territorial management since the development of the ESDP in the 1990s.

In the words of Faludi (2010), the macro-regional concept, as elaborated in the EUSBSR, appears to build upon and promote ideas of territorial cohesion, coherence and cooperation. However, it does not supply any new instruments, legislation or funding. Instead it collects and highlights diverse and often already existing initiatives and instruments within a Baltic Sea Region framing, adding a macro-regional perspective. Busek \& Gjoreska (2010:11) argue that EU macro-regions can be conceptualized as "interaction spaces" that offer "the advantage of flexible definition and shaping". In a similar vein, Stead (2011) suggests that the emergent EU macro-regions might gainfully be investigated as emergent 'soft spaces', as defined by Allmedinger \& Haughton with collaborators (see Allmendinger \& Haugthon 2009, 2010; Haughton et al, 2010). In this paper, we do not only wish to pick up on this suggestion, but also investigate further how the governance structures underpinning the strategy and its application might also be considered as metagovernance practices, or that which Stead calls 'soft planning' in his brief commentary.

Figure 1. Adopted macro-regional strategies of the European Union, as of June 2011 


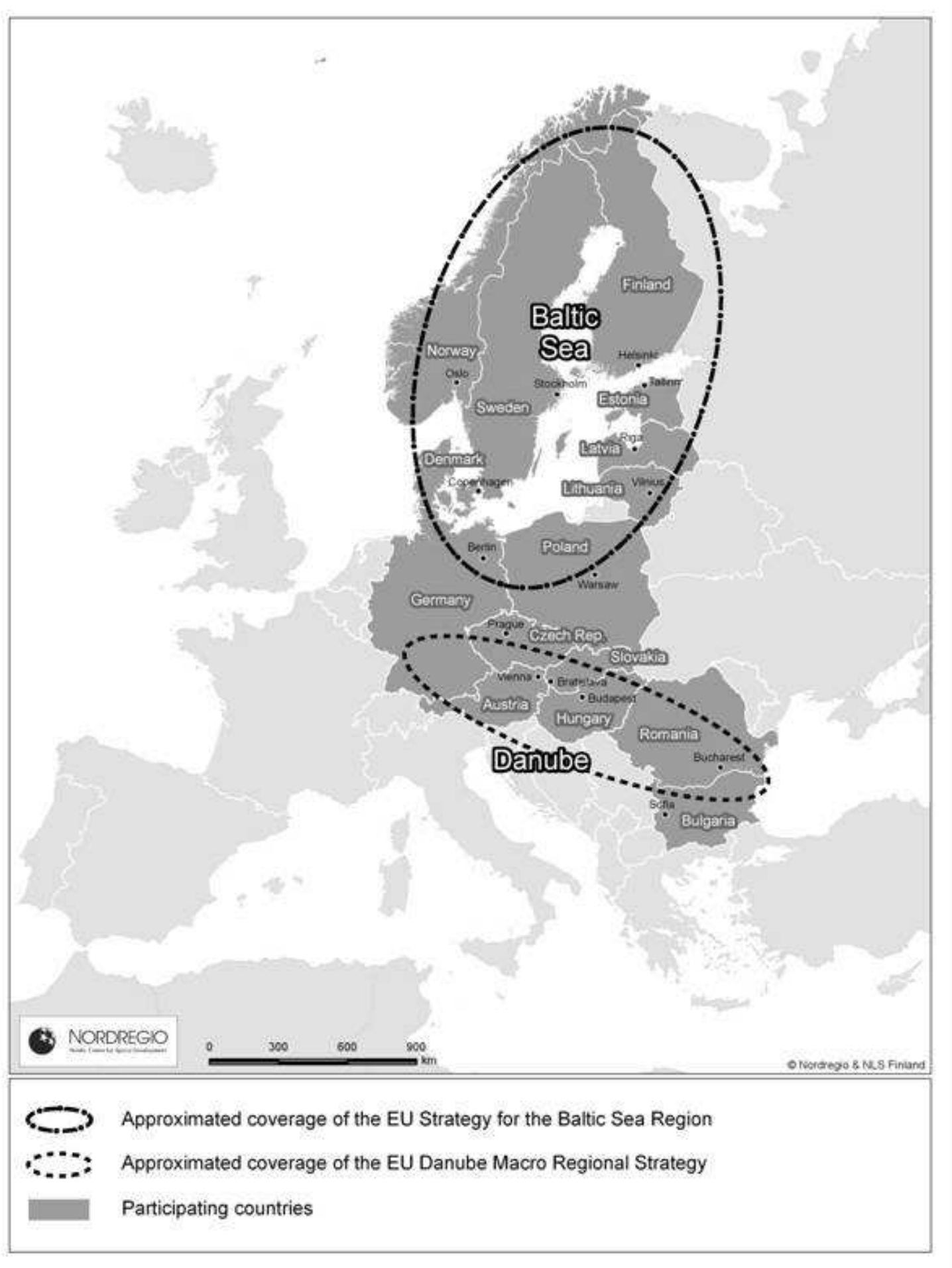

Source: Own illustration 
Further, it is argued that if we are to understand the specific context within which the EUSBSR has been developed, we must situate the strategy within the longer process of Baltic Sea regionalization, in which the formulation and application of the EUSBSR is but one, albeit potentially highly important, step. Examining the EUSBSR as a transnational spatial planning endeavour also opens interesting questions regarding its status as a 'soft space'. Could it be that the planning processes underpinning the formulation and application of the strategy can be seen to be contributing to the solidification of the soft space of the Baltic Sea Region?

To pursue the line of investigation outlined above, the second section of this paper contains a review of contemporary discussions on soft spaces and related practices of territorial metagovernance, and an attempt is made to bring the valuable insights from these discussions in relation to ideas from Actor-Network Theory (ANT) and regionalization theory, which allows for a contextualization of the spatiotemporal specificities of contemporary European soft spaces within a broader theoretization of the formation processes of spatial entities. Particular emphasis is placed upon examining the ANT-concept of the 'spokesperson' and how spatial planning practices sometimes may contribute to the establishment of territorial spokespersons as an important step in the stabilization of a particular spatial entity. In the following, third section, we examine the development of the EUSBSR as a form of spatial 'hardening process', and particularly highlight one specific outcome of this process: the emergence of the European Commission as a designated spokesperson for the interests of the wider Baltic Sea Region. In the fourth and final section we bring together our observations concerning the EUSBSR with our theoretical discussions. Here we further discuss the implications of conceptualizing the Baltic Sea Region as a soft 
space in a process of gradual hardening, and how such a perspective might lead us onto some broader insights regarding the formation processes of spatial entities such as regions. It is suggested that one must not take for granted that increased degrees of institutional formalization of spatial entities such as regions necessarily also translates into heightened levels of institutional durability. 


\section{Soft spatiality, regionalization theory and ANT}

\section{Contemporary soft spaces of spatial planning and planning-as-metagovernance}

Building upon thorough empirical investigations of the practices and institutions of contemporary British spatial planning, Allmendinger \& Haughton with collaborators have highlighted the emergence of numerous entirely new planning scales in the form of "soft spaces" with "fuzzy boundaries", consisting of informal or semi-formal non-statutory spatialities of planning with associations and relations stretching across both formally established boundaries and scalar levels of planning and previously entrenched sectoral divides (Allmendinger \& Haughton, 2009, 2010; Haughton et al, 2010). These emerging soft spaces of planning can to various degrees be seen to both supplement and supplant existing 'hard', i.e. formally recognized and statutorily defined planning spatialities.

Allmendinger \& Haughton connect the emergence of the new soft spaces of planning to the development of British spatial planning practice in 1990's and early 2000's, where spatial planning to an increasing degree was utilized to attempt to achieve policy integration and coordination across organizational and institutional boundaries by providing territorial framings for strategic perspectives on a wide range of policy issues such as land development, environmental concerns, resource use, transport, economic development, social infrastructure, and similar concerns. Similar developments could also be observed across Europe (Deas \& Lord, 2006; Schmitt, 2009). From having been a primarily regulatory activity, spatial planning activity is thus to an increasing becoming focused upon the type of activities that Jessop (2004) refers to as "metagovernance" practices, whereby processes of policy integration, consultation and coordination are rigged and steered. 
According to the definition given by Haughton et al. (2010:46), metagovernance can be seen as a "complex process for creating shared understandings of acceptable behaviours, enforced through diverse mechanisms, not least the shared involvement in creating strategic documents required by the policy integration agenda, and agreement on the instruments for ensuring conformity". Metagovernace is thus a form of "governance of governance" (Allmendinger \& Haughton, 2010: 808), whereby the "rules of the game" are codified and policies are scripted.

The work done by Allmendinger \& Haughton on soft spaces with fuzzy boundaries and planning-as-metagovernance provides us with a vocabulary that can capture the contemporary dynamics of spatial organization and the role(s) of planning therein. Their meticulous empirical investigations allow them to frame their observations of the rapid evolution of contemporary planning practices within the context of broader, and perhaps even fundamental social, economic and cultural developments within Europe and globally. Thus, the authors situate their theorizing as an analysis of a specific, dawning epoch of socio-spatial organization in Europe. This clear spatiotemporal framing of their observations provides an important contribution to a diagnosis of contemporary practices of territorial governance, but at the same time risks to obscure some of the potential wider implications of their observations, and the ways in which their perspectives may also provide us with tools that can help us develop our general understanding of some of the processes through which spatial entities such as regions take form and evolve. Allmendinger \& Haughton have repeatedly also noted that we can see that soft spaces of planning are often initially marked by fuzzy boundaries (see Allmendinger \& Haughton, 2009:619, 2010:231), leaving open the possibility that the external boundaries of these soft spaces in the future might be defined 
in more definite terms. Adding to this, we would further also like to suggest that this potential for an evolutionary rigidization of the spatial form of soft spaces not only applies for the 'fuzziness' of externally boundaries, but also concerns the consistency of the these spatialities, which might not always stay so soft either. Rather, we will sometimes be able to observe processes of solidification, whereby soft spaces are transfigured into harder, more clearly regulated and governed spaces, through the establishment of more rigid and strictly formatted and regulated sociomaterial forms of spatial organization. To find some conceptual handles that may give us a grip on such processes of spatial hardening we will in the following sections turn our attention to aspects of Actor-Network Theory (ANT) and regionalization theory to find ways through which the discussions on soft spatiality and planning-as-metagovernance might be opened up into a broader discussion on the formation processes of spatial entities.

\section{ANT, regionalization theory and the formation processes of spatial entities}

Spatial planning work can be described as always beginning 'in the middle', in a situation constrained by multiple factors that for different reasons are beyond the control, and often even the knowledge, of the planner (Hillier, 2007). To understand this "in the middle"situation of planning practice, it is important that we analyse planning work and planning exercises as being situated within wider processes of spatial formation - processes that have been extensively theorized by prominent scholars such as Anssi Paasi within the literature of the research field that we perhaps might call regionalization theory (cf. also Giddens, 1984; Jones \& MacLeod, 2004; MacLeod \& Jones, 2001; Pike, 2007). Paasi (2010) has hinted that an interesting route for the further development of regionalization theory could be by way of an encounter with the thinking of Actor-Network Theorists such as Bruno 
Latour. Taking our cue from this tacit suggestion, this section of the paper attempts to experimentally draw together regionalization theory - as articulated by Paasi - with insights from Actor-Network Theory (ANT), a school of thought that to quite some extent has concerned itself with questions about how localities, scalarities and spatialities come into being, evolve and dissolve. ANT has gainfully been translated into geographic research through the works of scholars such as Thrift (see for instance Bingham \& Thrift, 2000; Thrift, 1996, 1999), Whatmore (2002) and Murdoch (1998; 2006), among others, but in the context of this paper the focus will be primarily upon the writings of some of the 'founders' of the approach, such as Bruno Latour and John Law.

Anssi Paasi (e.g. 1986, 2002a, 2002b), has persistently argued that regions should be analyzed as congealed, or at least partially stabilized products of processes of regionalization, which are always interventions in the world, and whereby the drawing up of boundaries, both tacit and explicit, and both internally and externally, effects of inclusion and exclusion are produced. As Painter (2010: 1094) reflects regarding the related concept of territory, regions (and other spatial entities) can be seen as "porous, historical, mutable, uneven and perishable... a laborious work in progress, prone to failure and permeated by tension and contradiction... never complete, always becoming". Thus conceptualized, processes towards regionalization go on all the time at all sorts of geographical scale levels (see Painter, 2008; Paasi, 2002a; Paasi, 2002b) making it a distinctly trans-scalar concept ${ }^{1}$ that more than anything highlights the manipulation of scale (Law, 1999) and the production of new scale units.

\footnotetext{
${ }^{1}$ The usage of the term "region" has historically in the EU context also been extremely wide, imprecise and polysemous, see further Faludi, 2010 and Busek \& Gjoreska, 2010.
} 
Further developing the insights of regionalization theory by relating them to ideas from ANT, we become able to see that processes towards regionalization are seldom streamlined, but are generally marked by strife and struggle over the right to determine the ascribed boundaries and substance of a certain regionalization. Thus, displacements and negotiations back and forth of what the region really is and should be will always occur in processes towards regionalization (cf. Latour 1987, 1999). As various actors intervene and propose new variations upon how we should conceive a certain region in the becoming, this often leads to situations with multiple and often conflicting suggestions as how to envision a certain region floating around at the same time, sometimes partially connecting (cf. Strathern, 2004), sometimes standing in direct conflict with each other or appearing as mutually excluding (cf. Callon, 1986; Callon \& Latour, 1981; see also Lagendijk, 2005). Following Law (2007) and Mol (1999), this means that we often cannot talk of the region in the singular, but must rather refer to it in the multiple, as simultaneously existing, alternative versions of a region that are often (but not always) mutually excluding. Still, at some occasions the developments towards a singularization of a specific region may occur, either due to the launching of intentional programmes of action or as the unintended outcome of the unfolding of events.

Singularization, as a general alignment of multiple versions of a region, is never absolute or incontestable (cf. Callon 1986; Latour, 1987). Rather, increased degrees of singularization must be seen as a form of ontological closure that makes active contestation more difficult and costly, as greater amounts of resources and allies need to be mustered to have a reasonable shot at prying apart the strong associations that may have become established through such a process. When a certain version of the region becomes all the more 
stabilized, fixed and formalized, it may in time become more or less of a "collateral reality" which is taken for granted and reproduced daily without much reflection (Law, 2009). From this perspective we can then see, as Murdoch (2006:19; following Harvey, 1996) suggests, that the formation of spatial entities, such as regions, are processes of alignment and stabilization, resulting in the "carving out "permanences'" from spatial flows, albeit with the further qualification that these 'permanences' must not be imagined as somehow eternal, rather as contingent upon the processes that create, sustain and dissolve them.

Nevertheless, relating back to Allmendinger \& Haughton's discussions on the soft and hard spaces of planning, it is in this context important not to confuse questions of spatial softness and hardness, understood as institutional formalization and fixation, with questions concerning the durability or fragility of spatial entities. As ANT-scholars have repeatedly argued, the latter is a question of the strength of sociomaterial linkages forged out of heterogeneous materials (see for instance Latour, 2005; Law 1986, 1992, 2001), while the former is rather an issue of grades of institutional formalization, codification and rigidity. As Latour has repeatedly shown, the 'hardwiring' or "delegation into more durable materials" of assumptions about the world into strictly formatted and formatting sociomaterial arrangements may be a successful way of stabilizing a particular fact or version of the world (see Latour, 1987, 1994, 1999). Still, as John Law has repeatedly cautioned (Law, 1992, 2001), we must take care not to confuse and conflate the degree of formalization or fixation of an entity with degrees of durability or stability. For instance Mol \& Law (1994) have argued that there is sometimes a certain specific resilience in more fluid forms and topologies. In their seminal 1994 paper, Mol \& Law discuss fluid spaces as phenomena that are continuously altering - as amorphous, but at the same time peculiarly robust in their 
resilient fluidity (Mol \& Law, 1994:662). But this fluid robustness only persists as long as there is "no single strongpoint to be defended in order to preserve continuity", no "need for fixed frontiers to be patrolled", no "need for police action to safeguard the stability of elements and their linkages" and "no network structure to be protected" - points well remembered for the conclusions of this paper.

\section{Planning work and spokesperson formation in regionalization processes}

Attempting to locate the potential role of planning endeavours in the stabilization of spatial entities, it is relevant to make an association to the sociologist Gabriel Tarde who noted that

in the emergence of social groups "there is always an associate that represents and personifies the group in its entirety, or else a small number of associates... who, each under a particular aspect, individualize in themselves the group in its entirety" (Tarde [1893]/1969:67). In relation to spatial entities such as regions, we may in line with the above quote from Tarde recognize that one of the important steps in the process towards the potential singularization, stabilization and institutionalization of a spatial entity the emergence of regional spokespersons who through "grouping talk" act as the mouthpiece or spokesperson of the ascribed interests of a specific entity (see Latour 1987, 2004, 2005). Thus defined, the 'territorial spokesperson' is a term that can be introduced to denote any actor that takes upon itself or is vested with the capacity to act as the voice of a specific spatial entity, such as a region. By producing discourse in the name of the region and in the name of the interests of the region, a regional territorial spokesperson claims status as a clearing house of regionality and takes upon itself the right to formulate the interests of the region and the power to define what belongs to the region and not (cf. Latour, 2005:31), hence both attempting to position itself as the legitimate embodiment of the voice of the 
region, and at the same time articulating a particular version of the supposed essence of region (see Cooren, 2010; Latour, 2004).

The dynamics of spatial planning processes sometimes contribute to the formation of regional spokespersons and the establishment of recognized spokesperson authority. Spatial planning work often involves intentional attempts at moving towards a widely shared ascription of territorial essence to a specific spatiality - and to further plot a trajectory towards the future for this same entity (cf. Healey, 2007, 2008). In the vocabulary of this paper spatial planning exercises - seen in the context of wider processes towards regionalization - can therefore be seen as attempts to align multiple existing and partially connecting or conflicting versions of a region into a common, coherent version.

As such, spatial planning must not only be seen as an activity that is reflexive of a region, or an attempt to steer the fate of a region. Rather it is also an activity that can be fundamentally constitutive to regionality as it attempts to ascribe an essence to, and draw the boundaries of a region. By attempting to define what the region is in the present, it articulates boundaries both internal and external and delineates both the geographical scope of a region and the elements of identity within that spatiality. Thus, planning enacts regions (Donaldson, 2006), which means that strategic spatial planning activities must be analysed as exercises in ontological politics (Law, 2009; Mol, 1999); because when planning processes function to establish and mobilize one specific, singular version of the region from the multitude of potential or possible alternatives, it also functions to guide this proposed regionalization into a specific trajectory towards the future by delimiting what can be considered to be realistic future developments for the proposed regionalization. 'Is's' and 
'ought's' become corollarily and simultaneously produced in the same process (see Latour, 2004).

If the task of establishing an accepted voice of the region is carried out with success and without encountering to much dissent and opposition, a very powerful/empowering process has taken place which in a way could be seen as the constitution of a regional 'Leviathan' (cf. Callon \& Latour, 1981), whereby the singular(ized) voice of the region comes to speak in the name of the multitude. If this multitude that is spoken for then accepts to be represented by a singular voice in this manner - when it accepts that this voice might legitimately speak in their name - the singularized voice is vested with a tremendous power, as multiple actors and related resources become aligned to it.

The establishment of a recognized spokesperson-function in planning processes is regularly assumed to be already settled prior to the commencement of planning activities. But contrary to this, it may be methodologically gainful to hold this 'already-there' assumption regarding spokespersonship in doubt when studying the unfolding of planning processes and to pay attention to the processes through which recognized spokespersonship is established and asserted, leaving open the question to whereas such authority is a prerequisite of the planning process, or whether it is established within the process or even partially as an outcome of the planning process itself. Thus, it may sometimes be the case that spatial planning exercises contribute to the establishment of recognized spokesperson authority as an important step in the stabilization or hardening of a particular spatial entity, as the recognition of spokesperson authority generates a strong singularizing force that may function to bring together existing conflicting versions of a specific spatial entity, such as a region, into one shared, coherent conception of the essence and interests of said region. We 
will now turn to investigate the empirical case of the transnational so-called Baltic Sea Region, where the application of spatial planning-as-metagovernance appears to be placing the European Commission in a position as a broadly recognized regional spokesperson leading to an apparent increase in the degree of solidification of the formerly distinctly soft space of the Baltic Sea Region. 


\section{The European Union Strategy for the Baltic Sea Region}

\section{The BSR: a soft space in emergence}

The emergence of the Baltic Sea Region (BSR) as a contemporary distinctly soft transnational space constituted by multiple, partially overlapping and conflicting articulations of the region can be traced back at least to the fall of the Iron Curtain. Among the Baltic nations the fundamental geo-political change that occurred through the dissolution of the Eastern Bloc was seen as a unique opportunity to reinvigorate transnational cooperation in the area (Dutkowski et al. 2009: 515; Lehti, 2009: 19). In the midst of this upheaval new notions about transnational cooperation in the Baltic Sea area came into circulation, through the introduction of discursive configurations such as 'Baltic Europe', 'Mare Balticum', the 'Scanno-Baltic Space' and, maybe most notably, 'The New Hansa' (Joenniemi, 1993: 163). The flurry of activities that followed generated various forms of networks and institutions and gave birth to numerous pan-Baltic governmental and non-governmental organisations. Even though the exact number is difficult to define, at present one can count around 40 active pan-Baltic organisations forming a veritable "sea of acronyms" with partly overlapping agendas and activities (Löwendahl \& Pursianen, 2009: 614; Sterling, 2008). ${ }^{2}$ Initiatives generally came from the western shores of the Baltic as part of the enthusiasm to include the new eastern Baltic Republics - Estonia, Latvia, and Lithuania - into a new European transnational community. But to the great surprise of some, soon enough it turned out that widespread dissensus existed regarding the desirability of a Baltic Sea

\footnotetext{
${ }^{2}$ Examples are: the Council of the Baltic Sea States, VASAB, the Baltic Sea States Sub-Regional Cooperation, the Union of Baltic Cities, Baltic 21, the Helsinki Commission, The Baltic Metropoles Network, the B7 Baltic Island Network, and the Baltic Development Fund.
} 
regionalization. While the western countries of the Baltic Sea area found themselves within an emerging process of neo-regionalization, the former communist republics were still focusing on consolidating national borders and institutions, and were busy crafting a national - and to some extent 'western' and European identity - wherein a label of 'Balticness' was not seen as very benefitting. This led to a mellowing out of the first scramble for regionalization of the Baltic Sea towards the end of the 1990s, when it thus seemed as if the proposed regionalization of the Baltic Sea Region was already a lost cause as a 'future-region' (Lehti, 2009:18).

Even if the BSR regionalization efforts of the 1990s failed to generate any lasting momentum, they still left a living heritage of a wide and disparate organizational patchwork of actors that still see themselves as part of, caring for and promoting a Baltic Sea Region.

Since then, transnational EU programmes, perhaps especially various INTERREG-initiatives, have functioned as a major driver of transnational cooperation within the Baltic Sea Region (Dühr et al, 2010, 236; Görmar 2009). The EU-enlargement in 2004 almost transformed the Baltic Sea to an EU internal sea, further enabling a deepening of cooperation around the Baltic Rim in general. Still, the articulations of the boundaries, interests and essence of the region have remained distinctly multiple and fuzzy in the numerous - sometimes overlapping, sometimes conflicting - strategies, visions, programmes and projects of the numerous groupings and actors engaged in articulating a Baltic Sea Region.

\section{Formulation of the EUSBSR: process and content}

Officially the birth of the EUSBSR can be traced to a conclusion of the European Council in December 2007 which called for a rapid response to the urgent environmental challenges 
related to the Baltic Sea. Even though novel in many ways, the macro-regional policy approach that was introduced in tandem with the initiation of the process behind the EUSBSR appears to present a continuity with previous lines of reasoning and argumentation within EU territorial cohesion policy (Dubois et al., 2009: 21; cf. Faludi \& Watherhout, 2002; Jensen \& Richardson, 2004). ${ }^{3}$ In early 2008 , the task to prepare the strategy was delegated to DG Regio, the EU Directorate for regional affairs, and its Unit for Territorial Cooperation, and during the following months a special EUSBSR task force performed what perhaps could be labeled as a major feat of 'shuttle diplomacy' - consulting and coordinating various DGs, nation states, multinational and transnational organizations, NGOs and regional authorities. Already in the initial, probing stages of formulating the strategy it became apparent that if relevant stakeholders were to be involved to share the concern of the environmental state of the Baltic Sea, there were also many other concerns being articulated by a wide array of different actors in the wider Baltic Sea area that needed to be taken into consideration in order to produce a viable strategy that would be accepted by a multitude of actors. Thus, according to a senior Commission official, a wide array of issues became entangled in each other in the very first stages of the strategy process, including environmental issues, security and economic well-being.

The further consultation process took place through a series of seminars and conferences within the BSR, partly organized in cooperation with important institutional actors in the region. In addition to these events an open consultation was initiated to comment on a draft version of the strategy to which all self-elected stakeholders were invited.

\footnotetext{
${ }^{3}$ Although there are important divergences between them, it should also be noted that the macroregionalconcept bears a distinct family resemblance to the 'Euroregion'-concept of the 1990's (see further Wise, 2000a and 2000b). Regarding the back history of the strategy, see Lehti (2009) and Joenniemi (2009) on the role of the EU parliamentarian Baltic Strategy Working Group and later the initiative by Sweden to invite the European Council to mandate the elaboration of a Baltic strategy primarily focusing upon the increasingly visible degradation of the marine environment and related issues (Joenniemi, 2009).
} 
An examination of the EUSBSR process as that presented above reveals that the methodology employed in the making of the EUSBSR followed what at this time was a rather unusual procedure in the context of EU territorial policy. ${ }^{4}$ The broad and reasonably open consultational approach that was developed in the process, and which aimed at tying together already existing interests, initiatives and projects (see further below), appears to have been constructed partially due to choice, partially due to necessity - as the Commission at the outset of the process clearly stated that there would be no new instruments, legislation or institutions developed in relation to macro-regionalizations within the EU (known as the "3 no's" of EU macro-regionalization).

The strategy as such (CEC 2009a, 2009b, 2010a) represents a novel way of formulating and delivering EU territorial policy. It can be construed as a geographically distinctly 'fuzzy' (Stead, 2011) or 'form follows function'-approach which refuses to demarcate fixed geographical boundaries for the region, instead aspiring to functioning as a comprehensive and inter-sectoral connection hub for the territorial coordination of policy delivery built on four central pillars: environmental protection, economic prosperity, accessibility and attractiveness, and finally, safety and security.

A basic general tenet of the strategy appears to consist of an ambition to be as nonimposing as possible, and to try to build upon the specific conditions of the wider Baltic Sea area with the aim of efficiently coordinating and facilitating the dialogue between all the existing multi-level initiatives that are already in place in the region (Dubois et al., 2009:32).

\footnotetext{
${ }^{4}$ As Haughton et al (2010:20) note, contemporary transnational regional projects in Europe have previously primarily been the sole business of small groups of experts and civil servants, and the resulting strategies and visions have primarily reflect the consensus reached within these restricted policy circles and did not have very much traction outside of them. This is to be seen, however, in sharp contrast to the EUSBSR which is not only firmly embedded among stakeholders in the BSR-region but also formally 'owned' by the European Commission and backed-up by other EU institutions such as the European Parliament and the Committee of Regions.
} 
A carrying principle is to supplement and coordinate previous and existing initiatives, thus introducing a dimension of 'European added value' by establishing a double vision where actors are induced to frame their activities in multiple spatial frames by attaching what perhaps could be called an EUSBSR 'brand' to their activities, and thus highlighting that what they are doing also should be seen as an activity that has positive effects for the whole Baltic Sea Region. The idea appears to be that by attaching the EUSBSR label to specific interventions that are considered gainful for the whole region, and therefore included in the official Strategy Action Plan, a sense of shared concerns and mutual assistance will arise building on a 'your concerns are also mine, if my concerns are also yours'-logic (see Dubois et al, 2009:25). As Dubois et al (2009:39) also note, this approach has resulted in a negotiation process in respect to what a potential future could look like for the macroregion, including the identification of trade-offs among a bundle of stakeholders representing different levels and diverging interests.

Both the structure of the EUSBSR strategy document and the process underpinning its formulation appear to aim at producing a tying-together of established interests and multiple diverging conceptualizations of the BSR into a seemingly coherent whole. Through the resulting alignment of ontologies, agendas and visions for the future of the BSR in a common, shared version of the region, the EUSBSR implicates a wide range of actors - both governmental and non-governmental - who become enrolled as both the carriers and constitutors of the Baltic Sea Region as it was articulated in the strategy document. Interesting to note is that both the process and the resulting strategy document clearly, although indirectly, puts the European Commission in a very central position in relation to the singularized version of the BSR region that emerges from the strategy process and 
documents. Even though officials from DG Regio repeatedly have attempted to downplay this emerging central role of the Commission in the unfolding of the process towards regionalization of the BSR - as the instigators and 'owners' of the strategy, the EU inevitably becomes positioned as a claimant to the status of legitimate regional spokesperson with the right to define the interests and essence of the BSR.

\section{(Meta)governing the implementation of the EUSBSR}

Perhaps the most eye-catching element in the EUSBSR is that which it ostensibly doesn't include, namely new legislation, instruments or institutions. Thus, it has been evident from the outset that the macro-regional strategies will have to be designed so as to fit into existing structural dynamics and institutional arrangements through the coordination of existing actors and organisations and their numerous programmes, agendas and available instruments. Senior DG Regio officials involved in working with the strategy have also related that the project was initially conceived of as a 'McKinsey-job', where DG Regio would step in an assume responsibility for running the process and drafting the strategy text, but then stepping out and leaving full responsibility for the application of the strategy to the involved stakeholders and project-owners. In-line with this distributed network implementation-model envisaged by the strategy taskforce, the strategy document itself does not define any outline for new governance arrangements for the coordination and implementation of the many actions/projects enumerated in the strategy. Nevertheless, due to the highly disparate nature of the proposed actions the constellations of involved stakeholders the question has arisen over how the inter-sectoral and far-reaching initiatives outlined in parts of the strategy ('horizontal actions') are supposed to be coordinated within the existing complex and diffuse multi-scalar governance setting in the BSR. What 
appears to have occurred is that the development and adoption of the strategy has created a demand for the installation of new modes of governance in order to literally 'fill' the organisational and institutional vacuum which has emerged as a result of the singularization of the region in one clearly formulated and aligned version accepted by a multitude of stakeholders, who now appear to see it as the responsibility of the emerging designated regional spokesperson (the Commission) to secure the stability and further integration of the solidifying spatial entity which is emerging as an outcome of the process.

As a partial response to these complications, the Commission has to some degree retreated from the more dogmatic distributed network implementation model that was initially envisaged for the strategy and instead proposed and adopted a framework for the coordination of efforts towards the further development and implementation of the strategy (see Figure 2).

Figure 2: The three main pillars of the EUSBSR governance structure to coordinate the multitude of actors and organisations involved in the implementation

- DG Regional Policy is in charge of the overall day-to-day coordination, monitoring and reporting to the European Council, in close partnership with the other Commission services on topics falling under their competence. The European Council is in charge of the broader policy development.

- A High-Level Group of officials from the EU27 Member States and a representative from the Committee of the Regions has been set up, and consults the Commission on all major developments. The European Investment Bank (EIB) is also invited to participate in meetings.

- National Contact Points (NCPs) have been appointed by all eight participating Member States to assist the implementation of the Strategy at the national level. (...)

Source: CEC (2010c) 
The chart below (figure 3) is an elaboration upon an official diagram as it is published in CEC (2010d), the purpose of which, as it is framed in the original document, is to "guide the priority area coordinators". However, beyond this it also gives an indication on how the governance structure related to the implementation and follow-up of the EUSBSR is envisaged by the Commission. Based on the three main pillars as listed in Figure 2, in our adaptation of the figure, we have made some supplements in grey colour. The grey dashed arrow shall also illustrate the direct influence by the Commission as being the key authors and advocates of the Strategy, making the ultimate decisions regarding what projects to grant so-called 'flagship'-status, and to some extent also on the formulation of resulting subprojects.

Figure 3: The role of the EU Commission/ DG Regio in the governance of the EUSBSR

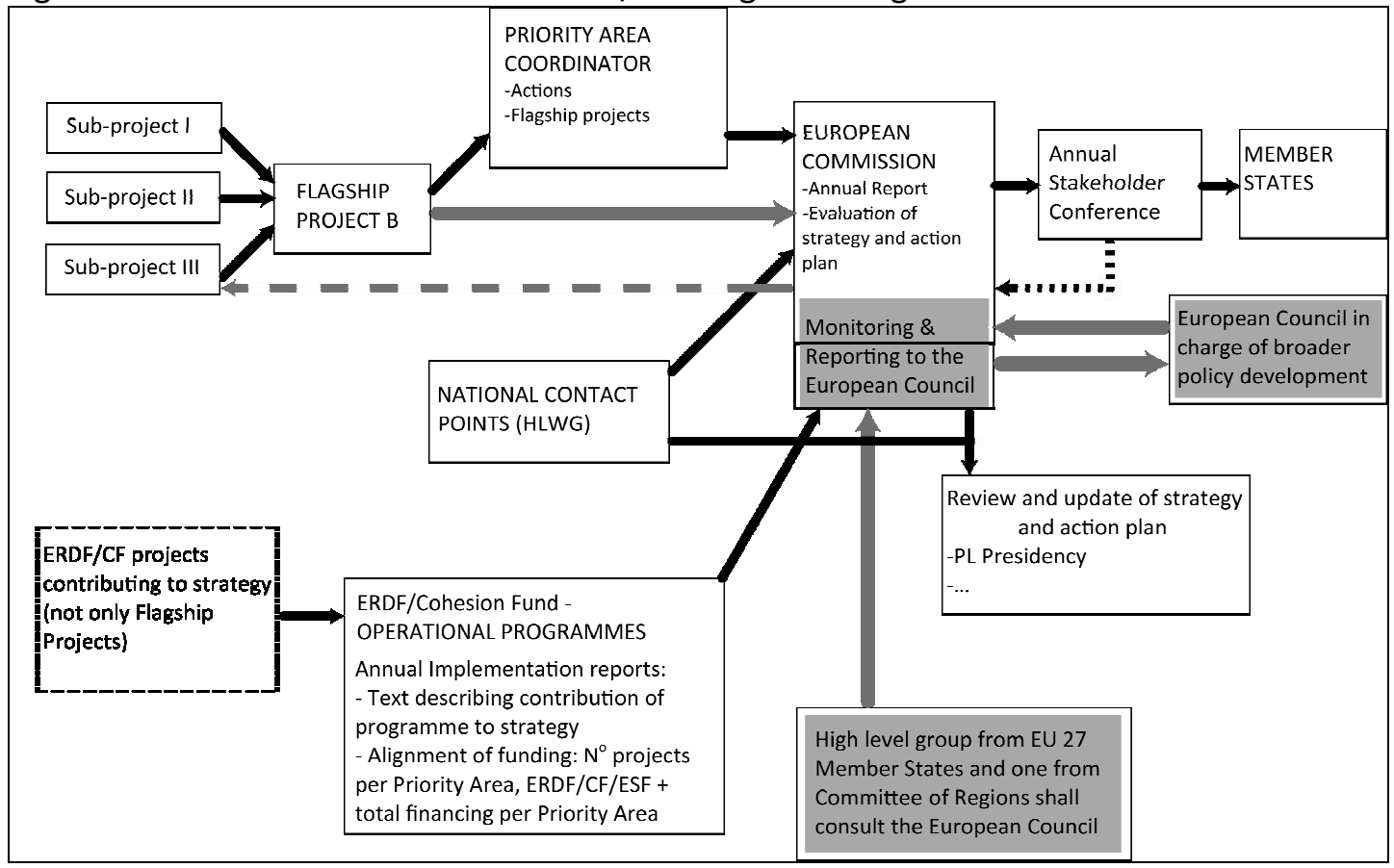

Source: adapted from CEC (2010d)

These supplements to the original commission figure underline the coordinating and controlling momentum on the side of the Commission. The other central component of the sketched governance structure is the strong involvement of the national governments, 
functioning as a counterweight to Commission influence, and further entangling them in the responsibility to implement the strategy. It can be questioned whether this (meta)governance framework can handle the a massive exchange of information envisioned in the description of the proposed structure for coordination or if, sooner or later, demands will arise for more extensive formal institutional structures for this. What is clear, however, is that DG Regio appears to be assigning itself a function as a clearing house for all matters relating to the EUSBSR strategy, with an ascribed role as a coordinator and monitoring agency for interactions in almost all thinkable directions. As such, the governance structure that is being put in place for coordinating and facilitating the implementation of the strategy most definitely bears the mark of a metagovernatial approach, putting the European Commission in the driving seat as the facilitator of the 'governance of governance' of the BSR through DG Regio. By putting themselves in a position where they - together with toplevel officials in the member countries - can act as the ultimate arbiters of what issues to propose to include in the strategy and not, which voices to listen to in the process and not, and further what actors to grant delegated responsibilities of implementation to and not, the European Commission could be seen to be acting to attempt to further secure and stabilize a privileged position as spokespersons for the essence and interests of the BSRregion.

The solidification of the soft space of the EUSBSR: regional spokesperson formation and planning-as-metagovernance

As has already has been suggested by Stead (2011), the EUSBSR-incarnation of the Baltic Sea Region appears to fit well with Allmendinger \& Haughton's description of a contemporary 'soft space' of planning which facilitates 'joined-up' governance through territorially 
integrating and drawing together both governmental and non-governmental institutions from agriculture, environmental protection, water management, education, economic development, policing, security and energy supply in a quasi-formalized and territorially fuzzy transnational policy setting. Nevertheless, when we position the soft space generated through the EUSBSR within the preceding history of BSR regionalization we can see that the content and territorial constituency of the paper, far from being evoked out of thin air, rather builds upon a long pre-history of efforts towards regionalization. During the two decades preceeding the development of the strategy, numerous invocations of a Baltic Sea Region with supposed pan-Baltic interests and a shared territorial essence were produced, and a wide array of governmental and non-governmental organizations were formed who see themselves as both part of and caring for the BSR, but all carrying their diverging and multiple - sometimes partially connecting, sometimes conflicting - articulations of the region. The many diverging and sometimes conflicting articulations of the interests and essence of the Baltic Sea Region in various mission statements, plans and visions can be seen to have generated a considerable level of ontological confusion, thus contributing not only to the wide diffusion of the idea of the existence of some form of regional spatial entity around the Baltic Sea, but also contributing to engendering a situation marked by an extremely high degree of 'spatial softness', as multiple versions of the region were in circulation concomitantly, without any actor able to assume a position as a singular, recognized spokesperson for the region.

When the European Commission then enters the scene by initiating the consultation processes leading up to the EUSBSR they begin to pick up and tie together many of the existing and sometimes conflicting versions of the region, and in the process also collecting 
and enrolling numerous actors into their strategy project and the common, shared and singularized version of the region that becomes articulated with it. Through aligning the multiple existing articulations of the region, its essence and interests, the Commission thus positions itself as the legitimate spokesperson of the BSR region, vested with the right to speak for and of the interests and essence of the region. Further, the Commission, after having been prompted to do so, has also moved to secure and stabilize this position through placing themselves in a central meta-governatial position within the emerging governance structure for the coordination and monitoring of the implementation of the EUSBSR. This emerging position of the Commission as a metagovernor within the BSR will most probably further facilitate the holding-in-place and protection of the singularized version of the BSR region articulated in the EUSBSR, by ensuring that it doesn't again break up into multiple, perhaps conflicting articulations.

Seen from the above perspective it becomes apparent that - even though ostensibly 'soft' the macro-region of the EUSBSR constitutes a distinct evolution of the conceptualization of the BSR in a direction towards a higher degree of spatial solidification through the singularization of previously multiple concomitant articulations of the region, and a stabilization of institutional arrangements. Still, as previously related in the theoretical section of the paper, we must take caution not to conflate or confuse such institutional fixity or hardness with durability. For as conceptualizations of the BSR now appear to be becoming more increasingly stabilized and singluarized through the EUSBSR and the Commission-centred governance network being put in place to implement the strategy, we also - following Mol \& Law (1994) - see the emergence of 'strongpoints in need of defence in order to preserve continuity' (DG Regio/European Commission), a rising need for 'police 
action to safeguard the stability of elements and their linkages' (stakeholders enrolled in the strategy) and the establishment of 'network structures to be protected' (the emerging EUSBSR governance arrangements). Thus, the institutional stabilization of the BSR that is occurring through the EUSBSR process at the same time also appears to produce new types of vulnerabilities and venues for challenge. Thus, it is important to see that the EUSBSR and the strong positioning of the European Commission as the mouthpiece of the emerging 'regional Leviathan' - so far must be seen as a raising of the ante on behalf of the Commission, a move which so far has not been seriously challenged in an open trial of strength by any actor either within or outside of the EU. For even if strong sociomaterial links have been forged through the EUSBSR process and the emerging related governance structure, the resulting solidification are in no way irreversible, and all bets are still on concerning whether the adoption of the EUSBSR in the end will prove to have constituted a real tipping point in the further solidification of a Baltic Sea Region. Most likely there will be some challenging tests of strength regarding the efficacy of the EUSBSR - in particular regarding its nominally 'material outcomes' and its influence in channelling streams of funding- in the coming years. Whether it will hold up to these challenges - which probably will be launched both from outside of and from within the EU administrative apparatus promises to be an interesting development to follow, and could potentially be one of the central issues in deciding the future path of EU cohesion policy. 


\section{Concluding discussion}

By placing the EUSBSR within the context of a wider and longer process of Baltic Sea regionalization, it becomes clear that soft spatiality gainfully can be related to as a particular stage in the formation processes of spatial entities. For even if the BSR macro-region of the EUSBSR appears to fit quite hand in glove with contemporary ideas of soft spaces of planning, we must not be tempted to settle for a static view of the formation processes of spatial entities such as the BSR. Instead, we may gainfully conceptualize spatial entities as emergent phenomena with a propensity to develop and evolve, but which periodically may also become institutionally stabilized to some degree. If we thus make an analytical choice to attempt to trace the development trajectories of spatial entities instead of focusing upon synchronic presences we might come to see spatial softness - structural flexibility and informal or semi-formal forms of territorial organization - not as an absolute property of certain spatial entities, and neither as eternal, but rather as a contingent stage in the development trajectories of some spatial entities.

By relating Allmendinger \& Haughton's reflections on contemporary soft spaces of planning to aspects of ANT and regionalization theory we become able to generate some conceptual handles that allows us to get a partial grip on some of the mechanisms where through competing or partially connecting versions of a specific spatiality can be singularized and temporarily stabilized. Particularly, and specifically relating to the empirical case of the EUSBSR, we become able to conceptualize how spatial planning processes generate the emergence of territorial spokespersons, claiming the right to speak in the name of the essence and interests of a particular spatial entity such as a region. Such territorial spokespersons in various ways may work to attempt to secure legitimacy and traction for 
their particular version of a spatial entity against other competing articulations of the same.

If the spokesperson can successfully manage to align other actors and their related resources to their particular version of the region, and to further hold them in place through various (meta)governance structures and techniques, such processes may contribute to generating a consensus among actors as to what constitutes the essence, the scope and the boundaries of a specific spatial entity. ${ }^{5}$ As a result, multiple and sometimes conflicting articulations of a spatial entity may to some degree become singularized and stabilized, eventually leading to the solidification of this entity through the generation of fixed and solid formal institutional forms.

Still, when studying the solidification of spatial entities, it is crucial to remember that these processes are in no way functionalistically determined or totally irreversible. Rather, we must recognize that forces constantly tug in multiple directions, and that it is always uncertain as to what actors or tendencies might come out on top to dominate in a specific and contingent historical episode. We must keep in mind that even though spatial entities might develop from some degree of softness to some relative degree of institutional rigidity, developments might as well go in the opposite direction - and also often do so in parallel: as one spatial entity hardens and becomes all the more 'actual', others are deactualized and wither away - perhaps to someday again become reactualized to a higher degree (the spatial entities of Scotland, Wales and Northern Ireland being a highly relevant example in this context). Thus, it is important not to see spatial 'softness' and 'hardness' as mutually

\footnotetext{
${ }^{5}$ In this context, the usage of the term "consensus" should be understood as simply denoting the reaching of a common agreement, in no way implying a necessarily normatively just solution. On the contrary, we can often observe that the establishment of consensual agreements among powerful actors generally depoliticizes sensitive issues in a way that conceals that choices being made in these processes often will reshuffle policy prioritizations and engender shifts in power relations, and there through inevitably generate 'winners' and 'losers' (see Allmendinger \& Haughton, 2010; Haughton et al, 2010; Metzger, 2011).
} 
exclusive dualistic properties, but rather as relative, gradient positions on a shared continuum of spatial closure and territorial definition.

Further, as previously discussed in the paper, we must also take caution not to confuse or conflate formal institutional fixity or hardness with properties of durability. Rather, as has been discussed within ANT, the durability of a phenomenon - such a as a spatial entity - is not only dependent on the fixity of sociomaterial forms, but rather on the strength and resilience of sociomaterial linkages. This means that spatial solidification, as the formalization of recognized and fixed institutions, does not necessarily imply a higher degree of conceptual durability. As related above, some very fluid and soft spatialities, such as those of the British so-called Home Nations of Scotland and Wales have remained distinctly resilient in a soft and fluid form for hundreds of years, before again becoming more clearly solidified in their institutional form during the past few decades. Although of a shorter history, the Baltic Sea Region now appears to be going through a similar process of solidification - albeit by ways of a different route. If this development from a soft and multiple state to more solid and singular existence also entails a movement towards a higher degree of durability remains to be seen - for we must take caution to remember that entities that are somewhat plastic are often highly resilient in their flexibility, whereas things that are rigid in their structure may sometimes easily come to break under pressure. 


\section{References}

Allmendinger, P. \& Haughton, G. (2009). Soft spaces, fuzzy boundaries and metagovernance: the new spatial planning in the Thames Gateway. Environment and Planning A 41(3) 617633.

Allmendinger, P. \& Haughton, G. (2010). Spatial planning, devolution and new planning spaces, Environment and Planning C 28(5), 803-818.

Bingham, N. T. \& Thrift, N. (2000). Some new instructions for travellers: the geography of Bruno Latour and Michel Serres, in M. T. Crang \& N. Thrift (eds.) Thinking Space, London: Routledge, pp. 281-301.

Busek, E. \& Gjoreska, A. (2010). The Danube Region: transformation and emergence, Eastern Journal of European Studies 1(1), 9-20.

Callon, M. (1986). Some elements of a sociology of translation: domestication of the scallops and the fishermen of St Brieuc Bay, in J. Law (ed.) Power, action and belief: a new sociology of knowledge? London: Routledge, pp. 196-223.

Callon, M. \& B. Latour (1981). Unscrewing the big Leviathan: how actors macrostructure reality and how sociologists help them to do so, in K. Knorr-Cetina \& A. V. Cicourel (eds.) Advances in social theory and methodology: Toward an integration of micro and macrosociologies. London: Routledge \& Kegan Paul, pp. 277-303.

CEC - Commission of the European Communities (1999). ESDP - European Spatial Development Perspective. Office for Official Publications of the European Communities, Luxembourg.

CEC - Commission of the European Communities (2007) Territorial Agenda of the European Union, Towards a More Competitive and Sustainable Europe of Diverse Regions, Inforegio Site [ec.europa.eu/regional_policy/cooperation/index_en.htm]

CEC - Commission of the European Communities (2009a). European Union Strategy for the Baltic Sea Region. Communication from the Commission to the European Parliament, the Council, the European Economic and Social Committee and the Committee of the Regions.

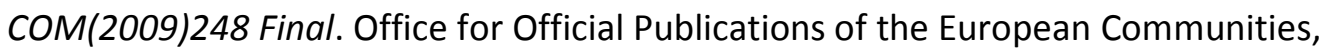
Luxembourg [www.ec.europa.eu/regional policy/cooperation/baltic/index en.htm, accessed 16 August 2010].

CEC - Commission of the European Communities (2009b). European Union Strategy for the Baltic Sea Region Action Plan. SEC(2009) 712. Office for Official Publications of the European Communities, Luxembourg [www.ec.europa.eu/regional policy/cooperation/baltic/pdf/communication/action2009.pdf , accessed 18 August 2010]. 
CEC - Commission of the European Communities (2010a). The European Union Strategy for the Baltic Sea Region - background and analysis. Office for Official Publications of the European Communities, Luxembourg [http://ec.europa.eu/regional_policy/cooperation/baltic/pdf/2010_baltic.pdf, accessed $26^{\text {th }}$ November 2010].

CEC - Commission of the European Communities (2010b). Action Plan - Working document accompanying the Communication concerning the European Union Strategy for the Baltic Sea Region - SEC(2009) 712 - May 2010

[http://ec.europa.eu/regional_policy/sources/docoffic/official/communic/baltic/action0520 102010.doc, accessed 26 November 2010]

CEC - Commission of the European Communities (2010c). Organisation of Work. [http://ec.europa.eu/regional_policy/cooperation/baltic/pdf/events/tallinn/annex3_organis ation_work.doc, accessed 26 November 2010].

CEC - Commission of the European Communities (2010d). Guidance to the priority area coordinators.

[http://ec.europa.eu/regional policy/cooperation/baltic/pdf/events/1009 warsaw guidanc e.pdf, accessed 26 November 2010]

Cooren, F. (2010). Action and agency in dialogue. Amsterdam: John Benjamins.

Deas, I. \& Lord, A. (2006). From a New Regionalism to an Unusual Regionalism? The Emergence of Non-standard Regional Spaces and Lessons for the Territorial Reorganisation of the State, Urban Studies 43(10): 1847-1877.

Donaldson, A. (2006). Performing regions: territorial development and cultural politics in a Europe of the Regions, Environment and Planning A 38(11): 2075-2092.

Dubois, A. \& Hedin, S. \& Schmitt, P. \& Sterling, J. (2009). EU macro-regions and macroregional strategies - A scoping study. Nordregio Working Paper 2009/4, Nordregio, Stockholm [www.nordregio.se/?vis=artikkel\&fid=5699, accessed 20 January 2010].

Dühr, S. \& Colomb, C. \& Nadin, V. (2010). European spatial planning and territorial cooperation. London, New York: Routledge.

Dutkowski, M. \& Görmar, W. \& Palmowski, T. (2009) Foundations for the development of the Baltic Sea Region and its spatial structures. Informationen zur Raumentwicklung, 8-9: 515-522.

Faludi, A. (2010). Centenary paper: European spatial planning: past, present and future, Town Planning Review 81(1), 1-22.

Faludi, A. \& Waterhout, B. (2002). The making of the European Spatial Development Perspective: no masterplan. London: Routledge.

Giddens, A. (1984). The constitution of society: outline of the theory of structuration. Cambridge: Polity Press. 
Görmar, W. (2009). Der Beitrag transnationaler Kooperationsprojekte zur Entwicklung der Ostseeregion. Informationen zur Raumentwicklung, 8-9: 629-640.

Harvey, D. (1996). Justice, nature and the geography of difference. Oxford: Blackwell. Healey, P. (2007), Urban Complexity and Spatial Strategies: Towards a Relational Planning for Our Times. London: Routledge.

Healey, P. (2008), 'Making choices that matter: the practical art of situated strategic judgement in spatial strategy-making', in J. van den Broeck, F. Moulaert and S. Oosterlynck (eds.) Empowering the Planning Fields: Ethics, Creativity and Action, Leuven: Acco, pp. 2341.

Haughton, G. \& Allmendinger, P. \& Counsell, D. \& Vigar, G. (2010). The New Spatial Planning: Territorial Management with Soft Spaces and Fuzzy Boundaries. Routledge, London.

Hillier, J. (2007). Stretching beyond the horizon: a multiplanar theory of spatial planning and governance. Burlington, VT: Ashgate.

Jensen, O.B. \& Richardson, T. (2004). Making European space: mobility, power and territorial identity. London: Routledge.

Jessop, B. (2004). Multi-level governance and multi-level metagovernance changes in the European Union as integral moments in the transformation and reorientation of contemporary statehood, in I. Bache \& M. Flinders (eds.) Multi-level Governance, Oxford: Oxford university press, pp. 49-74.

Joenniemi, P. (1993). Regionalization in the Baltic Sea Area: Actors and Policies, in: P. Joenniemi (ed.) Cooperation in the Baltic Sea Region, Washington: Taylor \& Francis, pp. 161178.

Joenniemi, P. (2009). The EU Strategy for the Baltic Sea Region: A Catalyst for What? DIIS Brief, August 2009, [http://kms1.isn.ethz.ch/serviceengine/Files/ISN/105107/ipublicationdocument_singledocu ment/3ddb42c8-b892-4d13-9cd5-bd9f1ee6eb47/en/pjo_eu_strategy_balticsearegion.pdf, accessed 18 November 2010]

Jones, M. \& MacLeod, G. (2004). Regional spaces, spaces of regionalism: territory, insurgent politics and the English question, Transactions of the Institute of British Geographers 29(4): 433-452.

Lagendijk, A. (2005). Regions and regional boundaries in the minds and practices of policymakers across Europe, in G. Van Vilsteren \& E. Wever (eds.), Borders and economic behaviour in Europe: a geographical approach. Assen: Van Gorcum, pp. 116-137.

Latour, B. (1987). Science in action: how to follow scientists and engineers through society. Cambridge, Mass.: Harvard University Press. 
Latour, B. (1994). On Technical Mediation: philosophy, sociology, geneaology, Common Knowledge 3(2): 29-64.

Latour, B. (1999). Pandora's hope: essays on the reality of science studies. Cambridge, Mass.: Harvard University Press.

Latour, B. (2004). Politics of nature: how to bring the sciences into democracy. Cambridge, Mass.: Harvard University Press.

Latour, B. (2005). Reassembling the social: an introduction to actor-network-theory. Oxford: Oxford University Press.

Law, J. (1986). On the Methods of Long Distance Control: Vessels, Navigation, and the Portuguese Route to India, in J. Law (ed.) Power, Action and Belief: A New Sociology of Knowledge?, Sociological Review Monograph 32. London: Routledge \& Kegan Paul, pp. 234263.

Law, J. (1992). "Notes on the Theory of the Actor-Network: Ordering, Strategy and Heterogeneity." Systems Practice 5: 379-393.

Law, J. (1999). Materialities, Spatialities, Globalities. Lancaster: Centre for Science Studies, Lancaster University. $\mathrm{Http}$ ://www.lancs.ac.uk/fass/sociology/papers/law-hetheringtonmaterialities-spatialities-globalities.pdf, accessed $15^{\text {th }}$ of March 2011.

Law, J. (2001). Ordering and Obduracy. Lancaster: Centre for Science Studies, Lancaster University. $\mathrm{Http}$ ://www.lancs.ac.uk/fass/sociology/papers/law-ordering-and-obduracy.pdf, accessed $15^{\text {th }}$ of March 2011.

Law, J. (2007). Actor Network Theory and Material Semiotics. Lancaster: Centre for Science Studies and Department of Sociology, Lancaster University.

Http://www.heterogeneities.net/publications/Law2007ANTandMaterialSemiotics.pdf, accessed $15^{\text {th }}$ of March 2011.

Law, J. (2009). Collateral realities. Lancaster: Department of Sociology, Lancaster University. Http://www.heterogeneities.net/publications/Law2009CollateralRealities.pdf, accessed $15^{\text {th }}$ of March 2011.

Lehti, M. (2009). Baltic Region in Becoming :From the Council of the Baltic Sea States to the EU's Strategy for the Baltic Sea Area, Lithuanian Foreign Policy Review (22): 9-27.

Löwendahl, B. \& Pursianen, C. (2009). Multilateral cooperation and spatial development, Informationen zur Raumentwicklung 8-9: 613-620.

MacLeod, G. \& Jones, M. (2001). Renewing the geography of regions, Environment and Planning D: Society and Space, 19(6): 669-695.

Metzger, J. (2011). Neither revolution, nor resignation: (re)democratizing contemporary planning practice, a commentary on Allmendinger \& Haughton's "Spatial planning, devolution, and new planning practices", Environment \& Planning C 29(2): 191-196. 
Mol, A. (1999). Ontological politics: a word and some questions. In J. Law \& J. Hassard (eds.) Actor Network Theory: and After. Oxford: Blackwell, pp. 74-89.

Mol, A. \& Law, J. (1994). Regions, networks and fluids: anaemia and social topology, in Social Studies of Science 24(4): 641-671.

Murdoch, J. (1998). The spaces of actor-network theory, Geoforum 29(4): 357-374.

Murdoch, J. (2006). Post-structuralist geography: a guide to relational space. London: SAGE.

Paasi, A. (1986) The institutionalisation of regions: a theoretical framework for understanding the emergence of regions and the constitution of regional identity. Fennia $164: 1,105-146$

Paasi, A. (2002a). Place and region: regional worlds and words, Progress in Human Geography 26(6): 802-811.

Paasi, A. (2002b). Bounded spaces in the mobile world: Deconstructing 'regional identity', Tijdschrift voor Economische en Sociale Geografie 93(2): 137-148.

Paasi, A (2010). Regions are social constructs, but who or what 'constructs' them? Agency in question, Environment and Planning A 42(10), 2296 - 2301.

Painter, J. (2008). Cartographic anxiety and the search for regionality, Environment and Planning A 40(2): 342-361.

Painter, J. (2010). Rethinking territory, Antipode 42(5): 1090-1118.

Pike, A. (2007). Editorial: Whither regional studies? Regional Studies 41(9): 1143-1148.

Schmitt, P. (2009). Raumpolitische Diskurse um Metropolregionen in Deutschland Positionen, Kontroversen, Perspektiven in J. Knieling \& A. Matern (eds.) Metropolregionen Innovation, Wettbewerb, Handlungsfähigkeit. Hanover: German Academy for Spatial Research, pp. 60-100.

Stead, D. (2011). European macro-regional strategies: indications of spatial rescaling?, Planning Theory \& Practice 12(1), 163-167.

Sterling, J. (2008). The Baltic Sea Region Organisations. Journal of Nordregio 1: 30-32.

Strathern, M. (2004). Partial connections. Walnut Creek: Alta Mira.

Tarde, G. De ([1893]/1969), Monadologie et Sociologie, translated by T. N. Clark, in T.N. Clark (ed.) On communication and social influence: selected papers. Chicago: University of Chicago Press.

Thrift, N. (1996). Spatial formations. London: Sage Publications.

Thrift, N. (1999). The place of complexity, Theory, Culture \& Society 16(3), 31-69.

Whatmore, S. (2002). Hybrid geographies: natures, cultures, spaces. London: SAGE. 
Wise, M. (2000a). The Atlantic Arc: Transnational European Reality or Regional Mirage? Journal of Common Market Studies, 38: 865-890.

Wise, M. (2000b). From Atlantic Arc to Atlantic Area: A Case of Subsidiarity against the Regions? Regional Studies, 34: 865-873. 